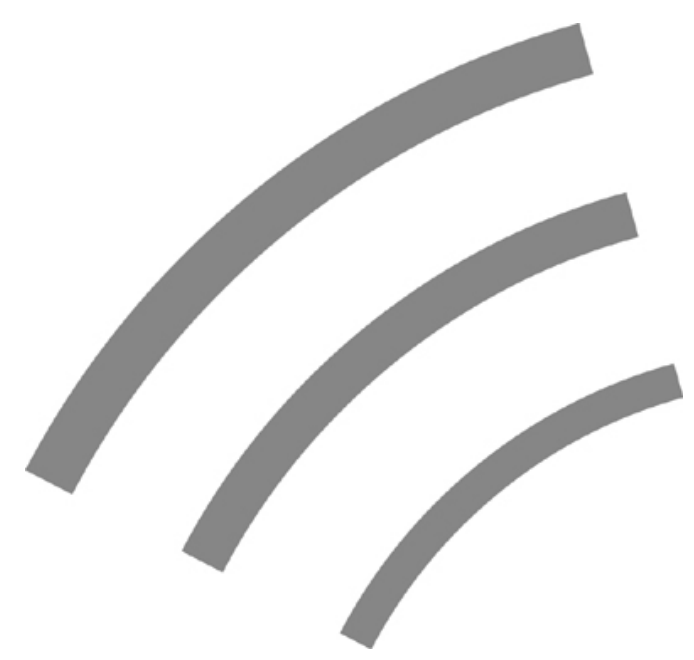

SCALES paper N200319

\title{
PROFESSIONAL HRM PRACTICES IN FAMILY OWNED-MANAGED ENTERPRISES
}

Jan de Kok*

Roy Thurik*

Lorraine Uhlaner*

* EIM and Erasmus University Rotterdam (CASBEC)

Zoetermeer, December 2003

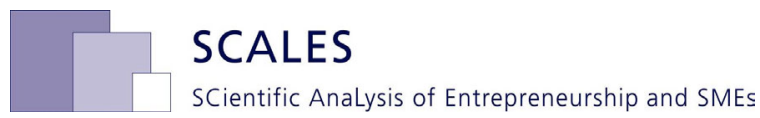


The SCALES-paper series is an electronic working paper series of EIM Business and Policy Research. The SCALES-initiative (Scientific Analysis of Entrepreneurship and SMEs) is part of the 'SMEs and Entrepreneurship' programme, financed by the Netherlands' Ministry of Economic Affairs. Complete information on this programme can be found at www.eim.nl/smes-and-entrepreneurship

The papers in the SCALES-series report on ongoing research at EIM. The information in the papers may be (1) background material to regular EIM Research Reports, (2) papers presented at international academic conferences, (3) submissions under review at academic journals. The papers are directed at a research-oriented audience and intended to share knowledge and promote discussion on topics in the academic fields of small business economics and entrepreneurship research.

$\begin{array}{ll}\text { address: } & \text { Italiëlaan } 33 \\ \text { mail address: } & \text { P.O. Box } 7001 \\ & \text { 2701 AA Zoetermeer } \\ \text { telephone: } & +31793413634 \\ \text { telefax: } & +31793415024 \\ \text { website: } & \text { www.eim.nl }\end{array}$

The responsibility for the contents of this report lies with EIM. Quoting numbers or text in papers, essays and books is permitted only when the source is clearly mentioned. No part of this publication may be copied and/or published in any form or by any means, or stored in a retrieval system, without the prior written permission of EIM.

EIM does not accept responsibility for printing errors and/or other imperfections. 


\section{Contents}

1 Introduction 5

2 Family ownership and management and professional HRM practices: Empirical and theoretical perspectives 7

2.1 Introduction 7

$\begin{array}{lll}2.2 & \text { Professional HRM practices } & 7\end{array}$

2.3 Agency theory and the family firm 8

2.4 The family firm and the resource-based view 9

3 Model and Hypotheses 13

4 Method 15

4.1 Sample and data collection 15

$\begin{array}{lll}4.2 & \text { Data analysis } & 16\end{array}$

5 Results 17

5.1 Scale formation for professional HRM practices 17

5.2 Descriptive and bivariate statistics 18

$\begin{array}{ll}5.3 \text { Discussion } & 20\end{array}$

6 Conclusions 23 



\section{Introduction}

Human resource management (HRM) has been defined as the "process of attracting, developing and maintaining a talented and energetic workforce to support organizational mission, objectives, and strategies" (Schermerhorn, 2001, p. 2400). Audretsch and Thurik $(2000,2001)$ argue that effective HRM practices are becoming increasingly important in the modern "knowledge-based" economy, as companies face the double challenge of the need for more highly trained employees coupled with the shortage of qualified labour. These challenges, coupled with the third trend toward smaller firms in general, reinforce the need for effective HRM practices in the small firm (Audretsch and Thurik, 2000, 2001).

Empirical research confirms that in general, smaller firms make less use of professional HRM practices than larger firms (Barron et al., 1987; Hornsby and Kuratko, 1990). For example, smaller firms make less use of formalized recruitment practices (Aldrich and Langton, 1997), provide less training to their employees (Koch and McGrath, 1996; Westhead and Storey, 1997, 1999) and are less likely to use formalized performance appraisals (Jackson et al., 1989). In spite of the size effect, a growing base of research evidence suggests that far from being homogeneous, small firms nevertheless vary widely in the professional HRM practices in use (De Kok and Uhlaner, 2001). For example, Deshpande and Golhar (1994) find HRM practices within many small manufacturing firms to be as sophisticated as those in larger companies. Similarly, Hornsby and Kuratko (1990) find that while firms of all sizes use primarily informal recruitment and selection techniques (mainly employee referrals and the interview), even among small firms, HRM practices are often more sophisticated than they had expected. Using a small set of cases, Hill and Stewart (1999) also demonstrate variation in level of sophistication of HRM practices among smaller organizations.

Variation in family ownership and management may help to explain the differences in HRM practices among SMEs. Although Dyer (2003) and Schulze et al. (2003) both point out that family is a neglected variable in organizational research, a research stream is emerging that generally confirms a negative relationship between family firm governance and the use of professional HRM practices (Aldrich and Langton, 1997; Fiegener, et al., 1996; Reid and Adams, 2001; Cyr, Johnson, and Welbourne, 2000). In this paper, we pursue this research stream further by deriving and testing a model to explain whether and why family-owned and -managed firms tend to use fewer professional HRM practices than other SMEs. In developing the propositions of the model, we compare and contrast predictions and explanations based on agency theory with those based on a resource-based view. We argue that the direct effect of family ownership and management on types of HRM practices found in SMEs is more consistent with agency theory whereas indirect effects, via various organization characteristics variables associated with greater organizational complexity and resource richness, may support a resource based view of the firm. The organization characteristics chosen for the present study include firm size, formal business planning, HRM specialization, and export strategy, thus representing a mix of contextual and structural characteristics (Daft, 1998). In addition, we control for other organization characteristics such as firm age, sector, unionisation and franchising. Before presenting the methodology and results of an empirical study of approximately 700 SMEs, we will review aspects the literature which provide conceptual support for the proposed model and hypotheses. 



\section{Family ownership and management and professional HRM practices: Empirical and theoretical perspectives}

\subsection{Introduction}

Research on HRM practices dates back to the early decades of the twentieth century (Scott, 1915). Between mid-century and the late 1970's HRM research primarily focused on the development of valid and fair HRM practices in large organizations (Asher, 1972; Campbell et al, 1970; Ghiselli, 1966; Guion, 1965) and sources of discrimination bias in hiring and promotion (Cann et al, 1981; Tenbrunsel et al, 1996). More recent research examines the impact of HRM practices on organization-level performance measures generally (though not always) supporting a positive linkage between the two (Delery and Doty; 1996; Guest, 1997; Huselid, 1995; Huselid et al, 1997; Ichniowski et al, 1997; Koch and McGrath, 1996; de Kok, 2001; Litz and Stewart, 2000; MacDuffie, 1995: Schulze et al, 2001; Schultze et al, 2003; Welbourne and Andrews, 1996; Wynarczyk, et al, 1993).

Past research confirms a negative relationship between family ownership and/ management and professional HRM practices and expertise. For instance, Aldrich and Langton (1997) find a negative relationship between the number of family members who work in a firm and formal HRM practices. Fiegener et al (1996) also confirm a negative relationship for promotion decisions. While non-family firms emphasize outside work experience and university training in promotion decisions, family firms rarely do so, in their study. Research by Reid and Adams (2001) confirms this pattern. In a study of Irish SMEs ranging in size from 20 to 100 employees, they find that family businesses are less likely to have professional HRM practices, including the use of references, appraisal systems, a peer appraisal process, training assessment, or merit-based pay.

Past researchers have drawn upon a wide variety of theories to explain the differences in professionalism of management and/or HRM practices between firms, and specifically between family and non-familyowned firms. We will focus in this study on two theories in particular: agency theory and the resourcebased view. First, however, we will discuss what we mean with professional HRM practices.

\subsection{Professional HRM practices}

Researchers variously refer to certain sets of HRM practices influenced by the HRM profession as "best practice," or "high-performance" (Huselid, 1995), "formal" (Aldrich and Langton, 1997; de Kok and Uhlaner, 2001; Heneman and Berkley, 1999), "sophisticated" (Golhar and Deshpande, 1997; Hornsby and Kuratko, 1990; Goss et al., 1994; Wagner, 1998) or as "professional" (Gnan and Songini, 2003; Matlay, 1999).The term, "high performance" has been used to describe management strategies found lined to higher performance in entrepreneurial firms (Chaganti, Chaganti, and Malone, 1991). This term has been adopted within HRM research as well. In particular, one of the lingering questions in HRM research is whether or not there is a single set of policies or practices that represents a 'universally superior approach' to managing people (Chandler and McEvoy, 2000, p. 44). Theories on best practices or high commitment theories suggest that universally, certain HRM practices, either separately or in combination are associated with improved organizational performance. They maintain that well-paid, wellmotivated workers, working in an atmosphere of mutuality and trust, generate higher productivity gains and lower unit costs (Boxall, 1996; Lowe and Oliver, 1991; Pfeffer, 1994). Some empirical research supports this view. For instance, Huselid (1995) reports from a sample of 968 firms that those using comprehensive employee recruitment and selection procedures, extensive employee involvement and training and formal performance appraisal approaches linked to incentives are likely to have lower employee turnover, higher productivity, and enhanced corporate financial performance. 
Others, however, argue that a contingency approach is more likely to generate superior performance with empirical research also supporting this perspective (Lawler and Jenkins, 1992; Meyer, Tsui and Hinings, 1993; Venkatraman, 1989; Gomez-Meijia and Balkin, 1992; Pilkington, 1998; Cappelli and Crocker-Heter, 1996). Research to date, though informative, does not unequivocally support either a best practices or a contingency view. Additional sampling is required to represent size, sector, and governance structures more fully. In addition, these need to be tested for the full range of HRM practices. Due to the limitations of research to date, we have thus also decided to avoid such labels as "best practice" and "high performance" for a defined set of HRM practices as premature.

Using the term, "formal", with reference to HRM practices is also problematic. The term, formal, (and/or formalization) takes on multiple meanings in the literature, (e.g. whether a practice is written, standardized and/or defined by the employer). See De Kok and Uhlaner, 2001. Certain HRM practices (e.g. use of psychological tests, performance pay, or referrals by employees) may be considered appropriate by experts but not necessarily formal, according to one or more of these definitions. Some researchers also use the term "sophisticated." But the term lacks a clear operational definition distinct from professionalism. This leaves us with consideration of the term, "professional." In the present study, the HRM practices chosen for study are derived primarily from experts in the field of HRM, whether or not the practice has been empirically validated against performance indicators within SMEs. However, such practices typically conform to legal requirements and professional standards established in a number of advanced Western economies in Europe, the United States, and elsewhere (and listed in such standard-setting bodies as the Society for Human Resource Management in the United States). We thus feel that this term is the most suitable for the present research.

\subsection{Agency theory and the family firm}

Agency theory focuses on the principals (owners) and agents (managers) of a company. Jensen and Meckling (1976) define agency costs as the sum of the principal's monitoring expenditures, the agent's bonding expenditures and the residual loss. 'Agency theory has been used in compensation theory to explain the steps that the owner (i.e., the principal) can take to bring the interests of managers (i.e., agents) into alignment (e.g., Welbourne and Gomez-Mejia, 1995). Heneman and colleagues suggest that agency theory may also be useful for study of other HRM practices (Heneman et al., 2000).

Steier (2003) applies agency theory to the family firm as follows: Since the owner (or principal) and manager (or agent) are typically part of the same family, monitoring, contracts or other coordination between the two should be more efficient and thus less expensive. If the owner and manager are one and the same, monitoring (of oneself) is obviously not even necessary, saving on agency costs. Randoy and Goel (2003) use this logic to assert that family firms may use more informal HRM practices to reduce costs and improve profitability. Pollack (1985) describes the potential advantages in the familyowned firm: incentives to act in the long-term interests of the family, effective monitoring of work activities, and selfless rationalities inherent in family grouping and loyalty to the family.

But this is not always the case. There are of course, situations where a relative does not perform well and other family owner/managers may be more reluctant to take action against a relative than against a nonperforming nonrelative for fear of damaging family relations, even if it is bad for the business.

Schulze et al (2003) refer to this latter phenomenon as a sort of altruism problem: a situation where the owner manager, by attempting to help other family members unintentionally and/or indirectly encourages them to shirk their duties. But others argue that such altruism, though leading to negative performance, does not necessarily change the impact of family firm governance on the types of monitoring

\footnotetext{
${ }^{1}$ For a more detailed discussion of the agency relationship, the reader is referred to Fama and Jensen (1983), Jensen and Meckling, (1976) and Steier (2003).
} 
devices used. For instance, Gomez-Mejia et al (2001) find that, even when faced with motivation and performance problems, families are often reluctant to monitor and discipline family members. Thus, even although Schulze et al (2001) do find a positive relationship within privately-held family firms between the use of monitoring systems and performance, this may not be due to increased agency costs. Greenwood (2003) argues by contrast that altruism may actually lower agency costs by removing the agency problem. In short, shirking and the altruistic behaviour it triggers may not necessarily alter the predicted direction of the effect: that owners of family-owned firms monitor agents less than do owners of non-family firms.

Following these arguments, we argue that family firms have less of a need to monitor agents in the firm (via performance appraisal), especially when they are from the same family. Even if their work is appraised, the basis for rewarding family employees is less likely to be related solely on their performance, and thus makes a professional compensation system also unnecessary. At least in smaller firms, recruitment is also simplified to the extent that family members are chosen over non-family members. Since the family owner-manager's expectations and goals influence the choice of HRM policy, it is thus seen as less likely that (especially smaller) family-firms will choose professional HRM policies.

In addition, family ownership is associated with a desire to remain independent and keep full control over the organization (Blais and Toulouse, 1990; Bacon et al., 1996). Case-studies suggest that employers often associate professional HRM practices with a loss of control over (and flexibility of) the employee relations (Koch and De Kok, 1999). This would provide an additional explanation for a direct negative effect of family ownership and management on professional HRM practices.

\subsection{The family firm and the resource-based view}

An alternative explanation for the relationship between family ownership and management and professional HRM practices is grounded in the resource-based view of the firm. The resource-based view is based on the assumption that differences in physical, organizational and human resources between firms cause a fundamental heterogeneity in their productive potential. Given this heterogeneity, the long-term competitiveness of a company depends upon the resources that not only differentiate it from its competitors, but are also durable and difficult to imitate and substitute (Hansen and Wernerfelt, 1989; Mahoney and Pandian, 1992; Barney, 1991; Prahalad and Hamel, 1990; Rangone, 1999; Priem and Butler, 2001). Resources are not meant only in the physical sense but refer to organizational capabilities as well (Ulrich and Lake, 1991). Human resources are an important resource to generate sustained competitive advantage through "facilitating the development of competencies that are firmspecific (...) and generate tacit organizational knowledge" (Lado and Wilson, 1994, page 699).

The resource-based view can be used to understand the impact of family ownership and management on other firm characteristics (Sirmon and Hitt, 2003). In this paper, we suggest that the resource-based view may form the basis for suggesting an indirect effect between family ownership and management and professional HRM practices. For example, Reid and Adams (2001) find that many family firms use less professional HRM practices, and explain this by suggesting such firms have more limited organizational capabilities. Past research supports the finding that family firms are less complex than non-family firms, in that they are often smaller (Daily and Dollinger, 1993; Donckels and Frohlich, 1991, Cromie et al., 1995, Westhead and Cowling, 1996). They are also less specialized or departmentalised (Reid and Adams, 2001; Cyr et al., 2000). In a study of Irish SMEs, Reid and Adams (2001) find that family businesses are less likely to have an HRM department. Cyr et al. (2000) find a negative relationship between the percentage of the firm owned by the CEO, a variable correlated with family ownership, and the presence of an HRM vice- president. Family firms are less likely to use formal accounting and planning practices than non-family firm counterparts, even when controlling for size and other factors (Jorissen, Laveren, Martens, and Reheul, 2002). Some researchers (e.g. Westhead and Cowling, 1996) suggest that it may not be family ownership and/or management per se that influences firm practices and performance, but indirect effects due to the fact that such firms often have more limited resources to in- 
vest, and choose less technical complex industries, and are thus are more constrained vis-à-vis resources available for company growth. In sum, the negative impact of family ownership and management on professional HRM practices may result from an indirect effect in that family firms tend to be smaller and less complex organizations, and with more limited resources.

To support the premise of an indirect effect based on the resource-based view, it is important not only to relate family ownership and management to (smaller) size and (less) complexity but also to demonstrate the links between size, complexity and other organization characteristics with professional HRM practices and to the resource based view. The remainder of this section provides a brief overview of this literature although it is beyond the scope of this paper to cover this literature exhaustively.

\section{Relationship between firm size and professional HRM practices}

As mentioned in the introduction, the link between firm size and professional HRM practices is well established. Most professional HRM practices require considerable development costs (Klaas et al., 2000). This results in a cost advantage for larger firms, which is strengthened by the limited supply of financial resources of many small firms. Company growth theories (Chandler and McEvoy, 2000; Galbraith, 1973; Gnan and Songini, 2003) also note the positive trend between firm size and complexity. As firms increase in size and complexity, they typically develop more layers of management and more formalized and/or systematized procedures and policies in order to process information more effectively within the organization (Galbraith, 1973). There are various explanations for this finding. For example, larger companies have a greater demand for human resources, and (thus, we assume) therefore a greater demand for specific HRM practices such as recruitment, selection and performance appraisal. This stimulates more professional development of these practices.

In attempts to explain these patterns, some scholars argue that an informal approach is more suited to the small firm. For instance, Hill and Stewart (1999) suggest that smaller firms should be more flexible and informal to be able to cope with the higher levels of environmental uncertainty. By contrast, others argue that it is lack of foresight and/or resources that leads to less use of professional HRM practices in small businesses. For instance, Hendry et al (1991) conclude that owners of small companies view any training beyond the level necessary to perform their immediate jobs as a luxury to be provided only when the firm is making large profits. And Golhar and Deshpande (1997) argue that a lack of understanding of HRM issues by small business owners may be one of the explanations for firm-size differences in HRM practices. Thus the problem may not only arise from limitations of physical capital but of human capital as well. Indirect confirmation of this latter explanation can also be found in results of a study of firm size and innovation by Damanpour (1992). In a meta-analysis of data from 20 published studies, he finds a strong positive relationship between firm size and innovation, indirectly supporting the argument that size is an advantage to firms, providing the resources needed to innovate (Damanpour, 1992). These results would appear to counter Hill and Stewart's argument that smaller size is an advantage.

\section{Specialization, formalization and professional HRM practices}

Specialization is typically associated with greater firm size (Bacon et al., 1996; Jackson et al., 1989; Wagner, 1997). Employees in smaller firms often have to perform a greater variety of tasks than do employees in larger firms, and specialists are less likely to be found in smaller firms. Heneman and Berkley (1999) confirm this trend within the HRM function. In a random sample of 117 companies with less than 100 employees, they find that only 15 have an HRM department. The negative relationship between firm size and HRM specialization (i.e., the presence of a specific HRM department and/or manager) is also confirmed in other research (Hornsby and Kuratko, 1990; Atkinson and Meager, 1994; Cyr et al, 2000). Damanpour provides an explanation for why specialization (or more generally structural complexity) is consistent with the resource-based view. "In complex organizations, coalitions of specialists in differentiated subunits increase the depth of the knowledge base, which in turn, increases the development of new ideas" (Damanpour, 1996, p. 695). In other words, greater specialization is associ- 
ated with greater knowledge resources. This assumption is indirectly confirmed by research by Damanpour (1996) using a meta-analysis from over 20 published studies showing a positive relationship between specialization and innovation.

Some research using the resource-based view sees strategic planning as a type of organizational capability (Michalisin, Smith, and Kline, 1997; Powell, 1992). Research specifically linking formal business planning and/or strategic planning to professional HRM practices is quite limited. However, in light of the previous discussion, it is logical to infer that firms with the organizational capabilities and resources to develop formal plans, are also more likely to have the resources to develop professional HRM practices. Furthermore, the availability of a business plan can be interpreted as a characteristic of organizations with a relatively long planning horizon. These firms will be more aware of the need to use professional HRM practices to build a competent employee base, implying a relatively high perceived value of HRM practices by the CEO. In addition, the presence of a formalized plan may reflect overall formalization levels in the organization.

Export strategy and professional HRM practices

Recent research on exporting links the existence of an export strategy with greater resource availability. For instance, Westhead, Wright, and Ucbasaran (2001) conclude that businesses with more resources, denser information and contact networks, and considerable management know-how are significantly more likely to be exporters (Westhead, Wright, and Ucbasaran, 2001). Also consistent with the resource-based view, Julien and Ramangalahy (2003) conclude that SMEs' limited capacity to acquire information and use sources is a major factor explaining their low level of involvement and performance in export markets. The exporting performance of SMEs is determined in part by their ability to acquire and manage foreign market information. Finally, Dhanaraj and Beamish (2003) find that three sets of resources including firm size, enterprise, and technological intensity, are good predictors of the export strategy of a firm. In sum, the presence of an export strategy within an SME may provide an indicator of an organization's ability to handle greater complexity and environmental uncertainty, which require access to more resources.

Summary of the resource based view and the family firm To summarize the main points of this section, we suggest that especially among SMEs, family ownership and management may be negatively associated with professional HRM practices due to resource limitations given their comparatively smaller size and reduced complexity, compared with non-family firms. In our study, in addition to firm size, variables which may reflect this reduced complexity include a (less) specialized HRM department or staff, less formal planning, and lack of an export strategy. 



\section{Model and Hypotheses}

In this section, we present the model and hypotheses to be tested in our research. The main characteristic of this model is that it distinguishes between a direct and indirect effect of family ownership and management on professional HRM practices. (See Figure 1). Hypothesis 1 predicts an indirect (negative) relationship between family ownership and management (referred to as the family firm variable in the model) and professional HRM practices via certain organization characteristics associated with greater complexity and/or richer organizational resources (arrows 1 and 2 in figure 1). The assumptions for this hypothesis draw upon resource-based model and the literature on organization complexity and uncertainty to suggest that family firms may use fewer professional HRM practices because they have fewer resources (typically being smaller) and therefore are less complex.

figure 1 Proposed Model: Influences on Professional HRM Practices

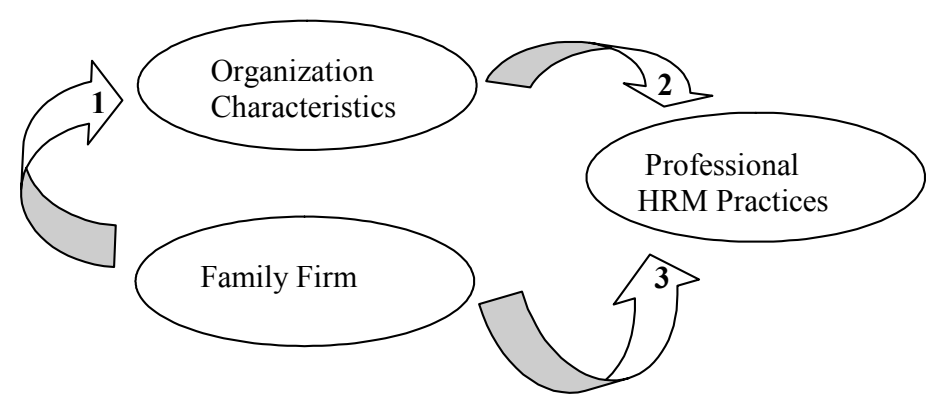

This hypothesis is consistent with a line of research on family firms carried out by Storey and colleagues, which found that the differences between family and nonfamily firms often reflect indirect effects based on other intervening factors such as firm size and sector (Westhead and Cowling, 1996). We state Hypothesis 1, as follows:

Hypothesis 1: Family firms have less professional HRM practices due to differences in certain organization characteristics associated with organizational complexity an/or resource availability.

To test Hypothesis 1, we include a limited number of variables to represent these organization characteristics, including firm size, the presence of formal business plans, HRM specialization either by department or individual manager and export strategy.

Hypothesis 2 predicts that at least part of the differences in the extent to which professional HRM practices are used by family and nonfamily firms cannot be attributed to differences in organization complexity or resource availability but rather to a direct effect of the family firm variable consistent with agency theory predictions (arrow 3 in Figure 1). We state Hypothesis 2 as follows:

Hypothesis 2: Family firms, even when controlling for certain organization characteristics associated with complexity and/or resource availability, are likely to have less professional HRM practices than similar non-family firms. 



\section{$4 \quad$ Method}

\subsection{Sample and data collection}

Data was collected by means of a written questionnaire sent to Dutch small and medium-sized enterprises. The questionnaire was developed by the University of Southern Queensland, Australia (Wiesner and McDonald, 2001). A first version of the questionnaire was submitted to a sample of 70 Australian SMEs, 31 of which responded. The results of this pilot were used to modify the questionnaire. Subsequently, it was submitted to several senior Australian academics in HRM for their comments. The revised questionnaire was then translated and further revised by Dutch HRM researchers and practitioners. A stratified sample plan was drawn distinguishing six sectors (manufacturing, construction, trade and repairs, catering, transport and communication, services) and three size classes (20-49 employees, 50-99 employees and 100-199 employees). Not all respondents fall within the originally defined sample classes. One hundred enterprises have either less than 20 or more than 200 employees. To avoid the loss of these observations, we decided to apply the Small Business Administration definition of SMEs (Flanagan and Deshpande, 1996), and to include all enterprises with 1 to 500 employees in our analysis.

Four thousand questionnaires were sent, addressed to the CEOs. Seven hundred thirty-six (736) questionnaires were received, $52 \%$ of which were answered by the CEO and $33 \%$ by an employee directly answering to the CEO, resulting in an $18 \%$ response rate. To check for sample selection bias by size and sector, we compare the response rates for the 18 strata. There does not appear to be a serious sample selection bias by either size or sector. Whether selection is biased by the respondent's attitude towards HRM cannot be determined. ${ }^{1}$

\section{Description and construction of variables}

The professional HRM practices scale was developed from a subset of questionnaire items on recruitment practices, selection methods and procedures, compensation, training and development, and appraisal. Each of these items is measured on a 3-point scale (1=no; $2=$ for some vacancies/jobs; $3=$ for all vacancies/jobs). A list of all items can be found in the Annex. The selected items all represent practices that are considered to be in accordance with professional standards and/or published "best practices" for approaching that particular area based on judgments by a multinational group of experts from Australia and the Netherlands. The professional HRM practices scale was created in three steps. First, a separate factor analysis was carried out using Principal Components Analysis and a Varimax rotated solution to identify relevant items for each of the five categories of HRM practices (recruitment, selection, compensation, training and development and appraisal. Second, the items selected for inclusion for each category was averaged to construct a separate subscale. To determine the reliability of these subscales, Cronbach alpha reliability coefficients were calculated for the selected items. Finally, the professional HRM practices scale was calculated as an unweighted average of the underlying subscales.

Organization characteristics variables chosen to represent different aspects of organization complexity include firm size, HRM specialization, formal business plan and export strategy. Firm size is measured as the log (number of employees), including employees with temporary contracts, with no correction for part-time work. To measure HRM specialization, respondents were asked two questions: whether or not an HRM department was present; and whether or not an HRM manager was present in the firm. These questions were then used to construct a dichotomous variable 'HRM specialization' where $0=$ neither HRM department nor HRM manager is present; 1=either an HRM department or HRM manager is present (or both). To measure the formal business plan variable, respondents were asked whether or not a

${ }^{1}$ Details of sampling can be found in De Kok, Thurik, and Uhlaner (2003). 
formal business plan or strategic plan exists $(0=$ no; $1=y e s)$. To measure export strategy, respondents were asked whether or not the firm exports $(0=$ no; $1=y e s)$.

The variable family firm was constructed as follows: A company received a score of 1 when it answered in the affirmative to both of the following questions: a) members of one family own this business and b) members of one family manage this business. No distinction was made between firms with single owner-managers and those in which two or more family members own and/or manage the firm. It received a score of 0 otherwise.

Finally, certain control variables were measured, including firm age, sector (service sector, trade sector and manufacturing sector), franchising $(0=$ no; $1=y e s)$ and the percentage of employees belonging to a union (below referred to as unionisation).

\subsection{Data analysis}

For hypothesis 1, two protocols were used to test for mediating effects of the organization characteristics variables; one proposed by James and Brett (1984) and the second, by Baron and Kenny (1986). According to Baron and Kenny (1986) one can test for the mediating effect of variable $m$ (organization characteristics), by first examining the relationship between proposed antecedent $x$ (family firm) and consequence $y$ (professional HRM practices), and then investigating the extent to which this relationship diminishes (or even vanishes) if mediating variable, $m$ is included in the model. Assuming significant relationships between $x$ and $y, x$ and $m$, and $m$ and $y$ (using bivariate tests), to support the inference that $m$ completely mediates the effect of $x$ on $y$, the effect of $x$ on $y$ (i.e. the t value for the unstandardized $b$ coefficient) should be significant in the model $y=f(x)$ but not in the model $y=f(m, x)$.

Based on the same starting premise of significant bivariate relationships between $x$ and $y, x$ and $m$, and $m$ and $y$, James and Brett (1984) compare the models, $y=f(m)$ and $y=f(m, x)$. If the added effect of $x$ (tested by the significance of the $R$-squared change when $x$ is added to the first model) is not significant, $m$ can be seen as completely mediating the relationship between $x$ and $y$. Conversely, a significant result provides support for a direct effect.

In this study we combine the two protocols by estimating three separate models: $y=f(x), y=f(m)$ and $y=f(x, m)$. We assume the presence of a mediating effect when the following requirements are met: a) significant effect of $m$ on $y$ in the model $y=f(m)$; b) a significant effect of $x$ on $y$ in the model $y=f(x)$; and c) a nonsignificant effect of $x$ on $y$ in the model $y=f(m, x)$. Likewise, we assume the presence of a direct effect in the case of a significant effect of $x$ on $y$ in the model $y=f(x)$ in combination with a significant added effect of $x$ on $y$ in the model $y=f(m, x)$.

A limitation of the above described protocols is that the relationship between the family firm and organization characteristics variables are established by looking at bivariate correlations. Since we hypothesize that family firm is related to organization characteristics, other than firm size, we elaborate on the protocol as follows: we control for firm size bias by estimating logistic regressions where the other organization characteristics (HRM specialization, formal business planning and export strategy) are related to the family firm variable as well as firm size. 


\section{$5 \quad$ Results}

\subsection{Scale formation for professional HRM practices}

The average scores, percentiles and reliabilities of the professional HRM practice subscales are presented in Table 1. For four of the five subscales, (all but appraisal) Cronbach alpha exceeds .60. According to criteria proposed by Nunnaly $(1967)^{1}$, the reliabilities for these subscales are acceptable for an explorative study. The reliabilities of these subscales are comparable with those reported by Huselid (1995) and Delery and Doty (1996). With a Cronbach alpha of .43, the reliability of the appraisal subscale is unsatisfactory. Given the importance of this subscale, we nevertheless decided to include it in our study.

Table 1 Scores and reliability statistics on subscales of professional HRM practices

\begin{tabular}{|c|c|c|c|c|c|}
\hline & Recruitment & Selection & Compensation & $\begin{array}{l}\text { Training and } \\
\text { development }\end{array}$ & Appraisal \\
\hline \multicolumn{6}{|l|}{ Score: } \\
\hline Mean & 1.6 & 2.0 & 1.8 & 1.7 & 2.0 \\
\hline $10 \%$ percentile & 1.3 & 1.5 & 1.3 & 1.0 & 1.3 \\
\hline $90 \%$ percentile & 2.0 & 2.8 & 2.2 & 2.3 & 2.7 \\
\hline \multicolumn{6}{|l|}{ Reliability: } \\
\hline Cronbach alpha & .62 & .69 & .64 & .81 & .43 \\
\hline Valid observations & 533 & 619 & 621 & 669 & 598 \\
\hline
\end{tabular}

note: all subscales are defined on the interval [1,3].

Due to missing data, none of the subscales can be calculated for all firms. This introduces the risk of a selection bias. To determine whether such a bias may occur, we examine for each subscale whether the respondents to that subscale differ significantly in their average scores on a number of variables compared to the non-respondents ${ }^{2}$. No significant differences in firm size are found between respondents and non-respondents. What does matter is the position of the respondent within the organization. For CEOs, the response rate is significantly lower than for other respondents ${ }^{3}$. This holds for all subscales, with the exception of the recruitment subscale. A possible explanation for this finding is that the CEO takes less time to fill in the complete questionnaire.

The professional HRM practices scale is calculated as an unweighted average of the underlying subscales. The resulting overall HRM scale is defined for 519 enterprises (Cronbach alpha equals .78).

\footnotetext{
${ }^{1}$ For early stages of basic research, Nunnally (1967) suggested that a Cronbach alpha between .5 and .6 would be sufficient.

${ }^{2}$ These control variables are size, sector, current working position of the respondent, location of the firm, current tenure of the respondent, whether the respondent is (part) owner, whether the company is owned by a family, whether the enterprise is member of a franchise organization, if a business plan is available, and the respondent's gender.

${ }^{3}$ the response rate is also lower if the respondent has a long tenure with the firm, or is (part) owner of the firm. Since ownership, tenure and being CEO are strongly related with each other, these differences in response rate are interpreted as confirmations of the CEO-effect.
} 


\subsection{Descriptive and bivariate statistics}

Table 5 in the Annex reports the means, standard deviations, and correlation coefficients between the major variables in this study. The relationships between each of the organization characteristics variables and professional HRM practices are all expected to be positive. This is confirmed by the bivariate correlations between professional HRM practices and all four organization characteristics variables, including firm size $(r=.41, p<0.01)$, HRM specialization $(r=.43, p<.01)$, formal business plan $(r=.35, p<0.01)$ and export strategy $(r=.19, p<.01)$.

The bivariate correlations between family firm and three of the four organization characteristics variables are fairly strong, statistically speaking, and negative (with firm size, $r=-.27, p<.01$; with HRM specialization, $r=-.29, p<.01$; with formal business plan, $r=-.24, p<.01)$. The correlation between the family firm variable and export strategy is somewhat weaker than for the other three relationships though still statistically significant at the 05 level $(r=-0.08 ; p<.05)$. To control for firm size bias, we estimate three logistic regressions, relating three organization characteristics (HRM specialization, formal business plan and export strategy) to family firm as well as firm size. In addition, we have included sector dummies as control variables (see Table 2).

Table 2 Results of logistic regression to examine the relationship between family ownership and three indicators of organisational complexity

\begin{tabular}{llll} 
& HRM Specialization & Formal Business & $\begin{array}{l}\text { Export Strat- } \\
\text { egy }\end{array}$ \\
\hline Family firm & $-0.78^{* *}$ & $-0.75^{* *}$ & -0.32 \\
Firm Size & $1.26^{* *}$ & $0.65^{* *}$ & 0.22 \\
& & & 0.06 \\
Firm Age & -0.11 & -0.11 & -0.22 \\
Trade sector & -0.02 & -0.21 & $-1.77^{* *}$ \\
Service sector & 0.34 & -0.09 & -0.49 \\
Other sector & $0.62^{*}$ & -0.12 &
\end{tabular}

\begin{tabular}{|c|c|c|c|}
\hline$\%$ predicted correctly $^{a}$ & $70(54)$ & $71(67)$ & $72(73)$ \\
\hline $\mathrm{R}^{2}$ (Nagelkerke) & 0.29 & 0.14 & 0.17 \\
\hline Chi $^{2}$ test for model parsimony ${ }^{b}$ & $7.79(0.099)$ & $2.2(0.70)$ & $71(0.00)$ \\
\hline Chi $^{2}$ test for model fit ${ }^{\mathrm{C}}$ & $161(0.00)$ & $68(0.00)$ & $81(0.00)$ \\
\hline Valid observations & 669 & 660 & 668 \\
\hline \multicolumn{4}{|c|}{$\begin{array}{l}\text { *: significant at } 5 \% \text { level } \\
\text { **: significant at } 1 \% \text { level } \\
\text { a: the reference value (the share of firms with HRM specialization/formal business plan/export strategy) is reported with } \\
\quad \text { parentheses. } \\
\text { b: test for the joint hypothesis that the parameters for age, trade, service and other sectors are equal to zero. Probabilit } \\
\quad \text { value within parentheses. } \\
\text { c: test for the hypothesis that all included parameters (except constant) are equal to zero. Probability value within } \\
\quad \text { parentheses. } \\
\text { d: the significance of the parameters is based upon both Wald statistics and Likelihood Ratio test statistics. Both test } \\
\quad \text { stad to the same conclusions. A constant term has been estimated, but is not included in the table. }\end{array}$} \\
\hline
\end{tabular}

The results support a broader interpretation of hypothesis 1 . That is, it is not just firm size, but other organization characteristics as well that probably mediate the relationship between the family firm variable 
and professional HRM practices. Only for export strategy we find that the relationship with the family firm variable is no longer significant, once we control for firm size.

Finally, we note that the bivariate relationship between family firm and professional HRM practices is significant and negative $(r=-.40 ; p<.01)$.

The significance and direction of the relationships between the family firm variable $(x)$, organization characteristics $(m)$ and professional HRM practices $(y)$ having been established, we can now test for the mediating effect of organization characteristics in the relationship between family firm and professional HRM practices. The estimation results of the regression models for $y=f(m, c), y=f(x, c)$ and $y=f(m, x, c)$ are presented as Models 1, 2, and 3 in table 3, where c represents additional control variables in the equation. In addition, the last column in table 3 reports the change in $\mathrm{R}^{2}$ for two separate analyses (either when a block is entered first-without the control variables; or last in the all-variable regression model).

Table 3 Results of ordinary least squares regression analyses on professional HRM practices

\begin{tabular}{|c|c|c|c|c|c|c|c|}
\hline \multirow[b]{3}{*}{ Explanatory Variables } & \multirow{2}{*}{\multicolumn{2}{|c|}{$\begin{array}{l}\text { Model } 1 \\
\text { Controls and Organi- } \\
\text { zation characteristics }\end{array}$}} & \multirow{2}{*}{\multicolumn{2}{|c|}{$\begin{array}{l}\text { Model } 2 \\
\text { Controls and Fam- } \\
\text { ily Firm }\end{array}$}} & \multirow{2}{*}{\multicolumn{2}{|c|}{$\begin{array}{l}\text { Model } 3 \\
\text { All Variables }\end{array}$}} & \multirow{3}{*}{$R^{2 \text { a }}$} \\
\hline & & & & & & & \\
\hline & $B$-value & $t$-value & $B$-value & $t$-value & $B$-value & $t$-value & \\
\hline \multicolumn{7}{|l|}{ Organization Characteristics } & \multirow[t]{5}{*}{$.30 * * / .20 * *$} \\
\hline Firm Size (log) & .09 & $5.16 * *$ & & & .07 & $4.40 * *$ & \\
\hline Formal Business Plan & .14 & $5.51 * *$ & & & .13 & $5.21 * *$ & \\
\hline Export strategy & .09 & $3.26 * *$ & & & .08 & $3.06 * *$ & \\
\hline HRM specialization & .16 & $6.11 * *$ & & & .13 & $5.28 * *$ & \\
\hline Family Firm & & & -.23 & $-9.05 * *$ & -.14 & $-6.01 * *$ & $.15^{* *} / .05^{* *}$ \\
\hline \multicolumn{7}{|l|}{ Controls } & \multirow[t]{10}{*}{$.01 / .01$} \\
\hline Firm Age (log) & -.01 & -.58 & .00 & .19 & .00 & .14 & \\
\hline Unionisation (\%) & .01 & -1.51 & .00 & -.30 & -.01 & -1.62 & \\
\hline Manufacturing sector & .05 & 1.67 & .04 & 1.03 & .05 & 1.62 & \\
\hline Service sector & .01 & .26 & -.02 & -.70 & .00 & .15 & \\
\hline Franchise & .09 & 1.65 & -.23 & -9.05 & .09 & 1.82 & \\
\hline Constant & 1.25 & $15.86 * *$ & 1.91 & $35.72 * *$ & 1.38 & $17.46 * *$ & \\
\hline R-square & .31 & & .16 & & .36 & & \\
\hline Adjusted R-square & .30 & & .15 & & .35 & & \\
\hline F-statistic & $22.86^{* *}$ & & $14.56 * *$ & & $25.78 * *$ & & \\
\hline
\end{tabular}

$* * p<.001-$ level.

$* p<.01$-level,

$\# p<.05 . a$

Change in $R 2$ when adding this variable first / last to the model (including all variables, i.e., organization characteristics, family firm; controls). Note: B-values refer to the unstandardized coefficients of the explanatory variables.

In a regression that only includes family firm as the independent variable, the unstandardized $b$ coefficient equals $-.23(p<.01)$, and this family firm effect explains approximately $15 \%$ of the variation in professional HRM practices.

Which part of this total family firm effect is mediated by organisational characteristics? This can be determined by looking at the third model reported in table 4 . In this full model, the family firm unstandardized $\mathrm{b}$ coefficient is $-.14(p<.01)$. The contribution to the $R^{2}$ when family firm is entered last in the equation, though reduced in magnitude, is still statistically significant ( $\left.R^{2}=.05, p<.01\right)$. We therefore 
accept hypothesis 2, and conclude that a direct effect of the family firm variable on professional HRM practices does exist.

In addition, we also accept hypothesis 1, concerning the presence of an indirect effect of the family firm variable on professional HRM practices with organization characteristics serving as intervening variables. This conclusion follows from the findings that, first of all, family firm is related to each of the organisation characteristics; secondly, that organization characteristics have a significant effect on professional HRM practices (in the first as well as in the third model in table 4); and finally, that the unstandardized $b$ coefficient for the family firm variable does decrease (from -.23 to -.14) when the effects of the organization characteristics are added into the linear regression model.

\subsection{Discussion}

The results from the present study support both hypotheses set forth; namely that firms with family ownership and/or management are less likely to use professional HRM practices, and that this may be due both to direct and indirect effects of the independent variable. It was argued that direct effects might be explained by agency theory and that indirect effects might be explained using the resource based view. Results appear to support, at least partially, both explanations however. In the discussion, we examine these premises more closely and discuss additional theories that should be considered in future research.

As mentioned in the introduction, agency theory provides one explanation for the direct effect. That is, the family firm effect is due in part to a decreased (perceived or actual) need for monitoring of the management by the ownership, since these may overlap in part, or in their entirety. However, organization control theory and institutional theory might also provide useful insights consistent with support for a direct effect. As pointed out by Gnan and Songini (2003), organizational control theory points out that clan and social control systems are more effective than the bureaucratic and administrative systems when strategy, decision making and power in the organization are managed by few people who share common values and coordinate themselves by informal relationships (Gnan and Songini, 2003, Mintzberg, 1983, Hopwood, 1974). It could be that in family firms, the social interactions among family members allow the use of informal and cultural mechanisms that substitute or complement the formal administrative systems. However, to test the accuracy of this explanation, future research is needed that would measure the effect of different HRM practices on performance.

Institutional theory may also help to explain the direct effect. Whereas agency theory focuses on the relationships between two specific stakeholders of an organisation, institutional theory typically examines additional stakeholders. Institutional theorists view organizations as entities that gain legitimacy and stakeholder acceptance by conforming to their stakeholders' expectations (Huselid et al., 1997; Paauwe, 1998). Examples of stakeholders are governmental institutions, professional organizations and certifying bodies (Baron et al., 1988; Tolbert and Zucker, 1983). In many industrialized nations, government institutions frequently play a key role in defining expectations in HRM practices, such as recruiting, selection, performance measurement, training, and the administration of compensation and benefits (Paauwe, 1998).

Williamson (2000) uses institutional theory to develop a strategic model of small business recruitment. In particular, he introduces the notion of employer legitimacy, defined as "a generalized perception or assumption held by job applicants that an organization is a desirable, proper or appropriate employer given the system of norms, values, beliefs and definitions that exist within an industry" (Williamson, 2000 , p.28). Williamson posits that to the extent an organization's recruitment procedures and other HR policies are viewed as proper and appropriate by potential job applicants, the organization will be seen as a legitimate employer. That is, small firms copy HRM practices of larger firms to gain employer legitimacy. But within this context, one might argue that the family firm has less need of legitimacy to the extent that it attracts family and friends to work for the firm. In addition, employer legitimacy in the 
family firm may derive less from the professional manner in which a firm handles its HRM policies than from ways in which family ties are managed.

From this discussion, it may be apparent that institutional theory and agency theory may lead to similar predictions. For instance, both theories are based on the premise that in family firms, the owner and manager stakeholder groups are likely to overlap and thus affect the types of practices in use. Institutional theory provides an additional explanation however for the presence of more informal HRM practices when not only the owner and manager, but the owner-manager and employee come from the same family. In particular, the firm may require less legitimacy from potential employees.

On the other hand, more than half the family firm effect is indeed explained by organization characteristics variables included in our model such as firm size, (presence of a) formal business plan, export strategy and HRM specialization. This is in line with the resource-based view of organizations. In particular, it is posited that these variables are likely to reflect greater resource availability and/or organization capabilities within the firm making it easier for the firm to develop professional expertise in HRM practices as well. Alternatively, these findings can be explained by the company growth theory, which suggests that as a company gets larger, the management task becomes more complex and requires a more professional approach. These relationships have been extensively documented in the literature (Perren, Berry and Partridge, 1999, Deakins, Morrison and Galloway 2002, Gnan and Songini, 2003). Furthermore, formal planning and control systems can help a family firm to cope with the challenges of family firm continuity as well (Ward, 1987). 



\section{Conclusions}

The primary purpose of this study is to examine and explain differences in the professional HRM practices between family and non-family owned and managed firms. We present a model concerning direct and indirect effects of family firm characteristics on the use of professional HRM practices.

We find that, based on our sample and model, family firms are less likely to use professional HRM practices than their counterparts. This family firm effect occurs not only indirectly (since family businesses tend to be smaller, and/or less complex than non-family businesses, where complexity stimulates the application of professional HRM practices), but also directly. The direct effects are consistent with predictions consistent with agency theory, which predict less monitoring in the family firm. On the other hand, the results cannot rule out other interpretations offered by organization control theory and/or institutional theory. Furthermore, the indirect family firm effect is consistent with predictions based on the resource-based view although once again, alternative interpretations of the findings cannot be ruled out.

We have not examined whether it is actually better or worse for family firms to rely upon less professional HRM practices. Lacking performance data, it is still possible to argue that family firms rely less heavily on professional HRM practices because it is unnecessary to do so, especially in many of the small firms within this study. Thus, future research is needed to examine relations between the use of professional HRM practices and performance for small firms, using family firm as a contingency variable. 



\section{References}

Aiken, M. and J. Hage, 1971, 'The Organic Organization and Innovation', Sociology 5, 63-82.

Aldrich, H. and N. Langton, 1997, 'Human Resource Management Practices and Organizational Life Cycles', in P. D. Reynolds, W. D. Bygrave, N. M. Carter, P. Davidsson, W. B. Gartner, C. M. Mason, and P. P. McDougall, (eds.), Frontiers of Entrepreneurship Research, Wellesley, MA: Babson College Center for Entrepreneurship, 349357.

Arthur, M. and C. Hendry, 1990, 'Human Resource Management and the Emergent Strategy of Small to Medium Sized Business Units', International Journal of Human Resource Management 1 (3), 233-250.

Asher, J. J., 1972, 'The Biographical Item: Can it be Improved?', Personnel Psychology 25, 251-269.

Atkinson, J. and N. Meager, 1994, 'Running to Stand Still: The Small Firm in the Labour Market, in: J. Atkinson and D. Storey (eds), Employment, the Small Firm and the Labour Market, London: Routledge.

Audretsch, D.B., A.R. Thurik, I.Verheul and A.R.M. Wennekers, 2002, 'An Eclectic Theory of Entrepreneurship: Policies, Institutions and Culture', EIM Research Report 0012/E, EIM, Zoetermeer, The Netherlands.

Audretsch, D.B., and A.R. Thurik, 2001, 'What is New about the New Economy: Sources of Growth in the Managed and Entrepreneurial Economies', Industrial and Corporate Change 10, 267-315.

Audretsch, D.B., and A.R. Thurik, 2000, 'Capitalism and Democracy in the $21^{\text {st }}$ century: From the Managed to the Entrepreneurial Economy', Journal of Evolutionary Economics 10 (1), 17-34.

Bacon, N., P. Ackers, J. Storey and D. Coates, 1996, 'It's a Small World: Managing Human Resources in Small Business', The International Journal of Human Resource Management 7 (1), 82-100.

Barney, J. B., 1991, 'Firm Resources and Sustained Competitive Advantage', Journal of Management 17, 99-120.

Baron, J. N., P. D. Jennings and F. T. Dobbin, 1988, 'Mission Control? The Development of Personnel Systems, U.S. Industry', American Sociological Review 53, 497514.

Baron, R.M., and D.A. Kenny, 1986, The Moderator-Mediator Variable Distinction in Social Psychological Research: Conceptual, Strategic, and Statistical Considerations, Journal of Personality and Social Psychology, 51 (6), 1173-1182.

Barron, J.M., D.A. Black and M.A. Loewenstein, 1987, 'Employer Size: the Implications for Search, Training, Capital Investment, Starting Wages, and Wage Growth', Journal of Labour Economics 5 (1), 76-89.

Blais, R.A. and J-M. Toulouse, 1990, 'National, Regional or World Patterns of Entrepreneurial Motivation?', Journal of Small Business and Entrepreneurship 7 (2), 3-20.

Boselie, P., J. Paauwe and P. Jansen, 2001, 'Human Resource Management and Performance: Lessons from the Netherlands', International Journal of Human Resource Management 12 (7), 1107-1125.

Boxall, P., 1996, 'The Strategic HRM Debate and the Resource-Based View of the Firm', HRM Journal 6 (3), 59-75.

Bronson, J.W. and C.P. Morgan, 1998, 'The Role of Scale in Franchise Success: Evidence from the Travel Industry', Journal of Small Business Management 36 (4), 3-20.

Campbell, J. P., M. D. Dunnette, E. E. Lawler and K. E. Weick, 1970, Managerial behaviour, Performance, and Effectiveness, New York: McGraw-Hill. 
Cann, A., W. D. Siegfriend and L. Pearce, 1981, 'Forced Attention to Specific Applicant Qualifications: Impact on Physical Attractiveness and Sex of Applicant Biases', Personnel Psychology 34, 65-75.

Cappelli, P., and Crocker-Hefter, A., 1996, 'Distinctive Human Resources are Firms' Core Competencies', Organizational Dynamics 24 (3), 7-22.

Chaganti, R., R. Chaganti, and Stewart M., 1991, High Performance Management Strategies for Entrepreneurial Companies: Research Findings from over 500 Firms, New York: Quorom Books.

Chandler, G. N., and G. M. McEvoy, 2000, 'Human Resource Management, TQM, and Firm Performance in Small and Medium-Size Enterprises', Entrepreneurship: Theory and Practice 25 (1), 43-58.

Chaston, I., 1997, 'Small Firm Performance: Assessing the Interaction between Entrepreneurial Style and Organizational Structure', European Journal of Marketing 31, 814-31.

Cromie, S., B. Stephenson, and D. Monthieth, 1995, 'The Management of Family Firms: An Empirical Investigation', International Small Business Journal 13 (4), 11-34.

Cyr, L. A., D. E. Johnson, and T. M. Welbourne, 2000, 'Human Resources in Initial Public Offering Firms: Do Venture Capitalists Make a Difference?' Entrepreneurship Theory and Practice 25 (1), 77-91.

Daft, R. L. 1998, Essentials of Organization Theory and Design, Cincinnati, Ohio: South-Western College Publishing.

Daily, C. M., and M. J. Dollinger, 1993, 'Alternative Methods for Identifying Familyversus Nonfamily-managed Businesses', Journal of Small Business Management 31 (2), 79-90.

Damanpour, F., 1996, 'Organizational Complexity and Innovation: Developing and Testing Multiple Contingency Models', Management Science 42 (5), 693-716

Damanpour, F, 1992, Organizational Size and Innovation, Organization Studies 13 (3), 375-402.

Deakins, D., Morrison, A., and Galloway, L., 2002, 'Evolution, Financial Management and Learning in the Small Firm', Journal of Small Business and Enterprise Development 9, 7-16.

De Kok, J.M.P. and L.M. Uhlaner, 2001, 'Organizational Context and Human Resource Management in the Small Firm', Small Business Economics 17 (4), 273-291.

De Kok, J.M.P., L.M. Uhlaner, and A.R. Thurik 2003, 'Human Resource Management with Small and Medium-Sized Enterprises: Facts and Explanations', ERIM Report Series ERS 2003-015, Rotterdam: Erasmus University.

Delery, J.E. and D.H. Doty, 1996, 'Modes of Theorizing in Strategic Human Resource Management: Tests of Universalistic, Contingency and Configurational Performance Predictors', Academy of Management Journal 4 (39), 802-835.

Desphande, S. and D. Golhar, 1994, 'HRM Practices in Large and Small Manufacturing Firms: A Comparative Study', Journal of Small Business Management 32 (2), 49-56.

Deshpande, S.P. and D.J. Flanagan, 1995, 'Union Representation Elections in Large and Small Manufacturing Firms: a Comparative Study', Journal of Small Business Management 33 (1), 56-65.

Dhanaraj, C. and Beamish, P.W., 2003, "A Resource-Based Approach to the Study of Export Performance", Journal of Small Business Management 41 (3), 242-261.

Donckels, R., and Fröhlich, E., 1991, 'Are Family Businesses Really Different? European Experiences from STRATOS', Family Business Review 4 (2), 149-160.

Dyer, W. G., 2003, 'The Family: The Missing Variable in Organizational Research', Entrepreneurship Theory and Practice 27 (4),401-416.

Fama, E., and Jensen M. C., 1983, 'Agency Problems and Residual Claims', Journal of Law and Economics 26, 325-344. 
Fiegener, M. K., Brown, B. M., Prince, R. A. and File, K. M., 1996, 'Passing on Strategic Vision', Journal of Small Business Management 34 (3), 15-26.

Flanagan, D.J. and S.P. Deshpande, 1996, 'Top Management's Perceptions of Changes in HRM Practices after Union Elections in Small Firms', Journal of Small Business Management 34 (4), 23-34.

Galbraith, J. R., 1977, Organizational Design, Addison-Wesley Publishing Company.

Galbraith, J. R., 1973, Organizational Development, Addison-Wesley Publishing Company.

Gales, L.M. and R. S. Backburn, 1990, 'An Analysis of the Impact of Supplier Strategies and Relationships on Small Retailer Actions, Perceptions, and Performance', Entrepreneurship: Theory and Practice 15 (1), 7-21.

Ghiselli, E. E., 1966, The Validatity of Occupational Aptitude Tests, New York: Wiley.

Gibb, A. A. 1997, 'Small Firms' Training and Competitiveness: Building upon the Small Business as a Learning Organization', International Small Business Journal, 15 (3), 13-29.

Gnan, L., L. Songini, 2003, 'The Professionalization of Family Firms: The Role of Agency Cost Control Mechanisms' FBN Proceedings 2003, 141-172.

Golhar, D.Y. and S.P. Deshpande, 1997, 'HRM Practices of Large and Small Canadian Manufacturing Firms', Journal of Small Business Management 35 (3), 93-97.

Gomez-Mejia, L. R., and Balkin, D. B., 1992, Compensation, Organizational Strategy, and Firm Performance, Cincinnati, $\mathrm{OH}$ : Southwestern.

Gomez-Mejia, L. R., Nunez-Nickel, M., Gutierrez, I., 2001, 'The Role of Family Ties in Agency Contracts', Academy of Management Journal 44 (1), 81-95.

Goss, D., D. Adam-Smith and A. Gilbert, 1994, 'Small Firms and HRM: Exceptions that Prove the Rule?', Journal of Small Business and Enterprise Development 1 (2), 2-8.

Greenwood, R., 2003, 'Commentary on: "Toward a Theory of Agency and Altruism in Family Firms"', Journal of Business Venturing 18, 491-494.

Guest, D. E., 1997, 'Human Resource Management and Performance: A Review and Research Agenda', The International Journal of Human Resource Management 8 (3), 263-276.

Guion, R. M., 1965, Personnel Testing, New York: McGraw-Hill

Hanks, S. H., Watson, C., Jansen, E. J., Chandler, G. N., 1993, 'Tightening the Life Cycle Construct: A Taxonomic Study of Growth Stage Configurations in HighTechnology Organizations', Entrepreneurship Theory and Practice 18 (2), 5-29.

Hansen, G. S. and B. Wernerfelt, 1989, 'Determinants of Firm Performance: The Relative Importance of Economic and Organizational Factors', Strategic Management Journal 10, 399-411.

Hendrickson, L. U. and J. Psarouthakis, 1998, Dynamic Management of Growing Firms: A Strategic Approach, 2nd edition, Ann Arbor, MI: The University of Michigan Press.

Hendry, C., A. Jones, M. Arthur and A. Pettigrew, 1991, Human Resource Development in Small to Medium Sized Enterprises, London: Employment Department.

Hendry, C. and A. Pettigrew, 1992, 'Patterns of Strategic Change in the Development of Human Resource Management', British Journal of Management 3, 137-156

Heneman, H. G. and R. A. Berkley, 1999, 'Applicant Attraction Practices and Outcomes among Small Businesses', Journal of Small Business Management 37 (1), 53 74.

Heneman, R.L., J.W. Tansky and S.M. Camp, 2000, 'Human Resource Management Practices in Small and Medium-Sized Enterprises: Unanswered Questions and Future Research Perspectives', Entrepreneurship Theory and Practice 25 (1), 11-26.

Hill, R. and J. Stewart, 1999, 'Human Resource Development in Small Organizations', Human Resource Development International 2 (2) 103-123. 
Hodge, B.J., Anthony, W.P. and Gales, L.M., 1996, Organization Theory: A Strategic Approach, Upper Saddle River, NJ: Prentice-Hall.

Hopwood, A. G., 1974, Accounting and Human Behaviour, Haymarket Publishing, London.

Hornsby, J. S. and D. K. Kuratko, 1990, 'Human Resource Management in Small Business: Critical Issues for the 1990s', Journal of Small Business Management 28 (3), 918.

Huselid, M.A., 1995, 'The Impact of Human Resource Management Practices on Turnover, Productivity, and Corporate Financial Performance', Academy of Management Journal 38 (3), 635-672.

Huselid, M.A., S.E. Jackson and R.S. Schuler, 1997, 'Technical and Strategic Human Resource Management Effectiveness as Determinants of Firm Performance', Academy of Management Journal 4 (1), 171-188

Ichniowski, C., C. Shaw and G. Prennushi, 1997, 'The Effects of Human Resource Management Practices on Productivity: A Study of Steel Finishing Lines', American Economic Review 87 (3), 291-313.

Jackson, S. E., R.S. Schuler and J. C. Rivero, 1989, 'Organizational Characteristics as Predictors of Personnel Practices', Personnel Psychology 42, 727-786.

James, L.R. and J.M. Brett, 1984, 'Mediators, Moderators, and Tests for Mediation', Journal of Applied Psychology, 69 (2), 307-321.

Jensen, M., and Meckling, O., 1976, 'Theory of the Firm: Managerial Behaviour, Agency Costs and Ownership Structure', Journal of Financial Economics 3 (2), $305-$ 360.

Jorissen, A., E. Laveren, R. Martens, A. Reheul, 2002, 'Differences between Family and Nonfamily firms: The Impact of Different Research Samples with Increasing Elimination of Demographic Sample Differences', Conference Proceedigns, RENT XVI, $16^{\text {th }}$ workshop, Nov. 21-22, 2002, Barcelona, Spain: Univeristat Autònoma de Barcelona.

Julien, P., and Ramangalahy, C., 2003, 'Competitive Strategy and Performance of Exporting SMEs: An Empirical Investigation of the Impact of Their Export Information Search and Competencies', Entrepreneurship Theory and Practice 27 (3), 227-245.

Klaas, B.S., J. McClendon and T.W. Gainey, 2000, 'Managing HR in the Small and Medium Enterprise: The Impact of Professional Employer Organizations', Entrepreneurship: Theory and Practice 25 (1), 107-124.

Kling, J., 1995, 'High performance work systems and firm performance', Monthly Labour Review 118 (5), 29-36.

Kotey, B. and G.G. Meredith, 1997, 'Relationships among Owner/manager Personal Values, Business Strategies, and Enterprise Behaviour', Journal of Small Business Management 35 (2), 37-61.

Koch, C.L.Y. and J.M.P. de Kok, 1999, 'A Human Resource Based Theory of the Small Firm', Research Report 9906/E, Zoetermeer, the Netherlands: EIM Small Business Research and Consultancy.

Koch, M. J. and R. G. McGrath, 1996, 'Improving Labour Productivity: Human Resource Management Policies Do Matter', Strategic Management Journal 17, 335354.

Lado, A.A. and M.C. Wilson, 1994, 'Human Resource Systems and Sustained Competitive Advantage: A Competency Based Perspective', Academy of Management Review 19, 699-727.

Lawler, E. E., and G. D. Jenkins, 1992, 'Strategic Reward Systems', In M. D. Dunnette and L.M. Hough (eds.), Handbook of Industrial and Organizational Psychology 3 (2), 1009-1055. Palo Alto, CA: Consulting Psychologists Press.

Lee, G. L., 1995, 'Strategic Management and the Smaller Firm', Journal of Small Business and Enterprise Development 2, 158-164. 
Legge, K., 1995, Human Resource Management; Rhetorics and Realities, London: Macmillan Business.

Litz, A. and A. C. Stewart, 2000, 'Research Note: Trade Name Franchise Membership as a Human Resource Management Strategy: Does Buying Group Training Deliver 'True Value' for Small Retailers?', Entrepreneurship Theory and Practice 25 (1), 125135.

Lowe, J. and N. Oliver, 1991, 'The High Commitment Workplace', Work Employment and Society 5 (3), 437-450.

Matlay, H. 1999, 'Employee Relations in Small Firms: A Micro-Business Perspective', Employee Relations 21 (3), 285-295.

MacDuffie, J. P., 1995, 'Human Resource Bundles and Manufacturing Performance: Organizational Logic and Flexible Production Systems in the World Auto Industry', Industrial and Labour Relations Review 48 (2), 197-221.

Mahoney, J. T. and J. R. Pandian, 1992, 'The Resource-Based View within the Conversation of Strategic Management', Strategic Management Journal 13 (5), 363-380.

Marlow, S. and D. Patton, 1993, 'Research Note-Managing the Employment Relationship in the Smaller Firm: Possibilities for Human Resource Management', International Small Business Journal, 11 (4), 57-64.

McEvoy, G.M., 1984, 'Small Business Personnel Practices', Journal of Small Business Management 22, 1-8

Meyer, A. D., Tsui, A. S., and Hinings, C. R., 1993, 'Introduction: Configurational Approaches to Organizational Analysis', Academy of Management Journal 36, 11751195.

Michalisin, M.D. Smith, R.D. and Kline, D.M., 1997, 'In Search of Strategic Assets', International Journal of Organizational Analysis 5, 360-387.

Mintzberg H., 1983, Structures in Fives: Designing Effective Organizations, Prentice Hall, New York.

Naylor, J. C., R. D. Pritchard and D. R. Ilgen, 1980, A Theory of Behaviour in Organizations, New York: Academic Press.

Nerkar, A.A., R.G. McGrath and I.C. MacMillan, 1996, 'Three facets of satisfaction and their influence on the performance of innovation teams', Journal of Business Venturing 11 (3), 167-89.

Neter, J., M.H. Kutner, Ch. J. Nachtsheim and W. Wasserman, 1996, Applied Linear Regression Models, Richard D. Irwin.

Ng, I. and D. Maki, 1993, 'Human Resource Management in the Canadian Manufacturing Sector', International Journal of Human Resource Management 4, 897-916.

Nooteboom, B., 1993, 'Firm Size Effects on Transaction Costs', Small Business Economics 5, 283-295.

Nunnally, J., 1967, Psychometric Methods, New York: McGraw-Hill.

Nunnally, J., 1978, Psychometric Theory, 2nd edition, New York: McGraw-Hill.

Paauwe, J., 1998, 'HRM and Performance: The Linkage between Resources and Institutional Context', RIBES paper 9854, Rotterdam, The Netherlands: Erasmus University Rotterdam.

Paauwe, J. and R. Richardson, 1997, 'Introduction Special Issue on HRM and Performance', The International Journal of Human Resource Management 8, 257-262.

Parks, S., 1995, Improving Workplace Performance: Historical and theoretical contexts, Monthly Labour Review 118 (5), 18-28.

Penrose, E. T., 1959, The Theory of the Growth of the Firm, New York: John Wiley.

Perren, L., Berry, A., Patridge, M., 1999, 'The evolution of management information, control and decision-making processes in small, growth orientated, service sector businesses', Small Business and Entreprise development 5 (4), 351-62. 
Pfeffer, J., 1994, Competitive Advantage through People, Boston: Harvard Business School Press.

Pilkington, A., 1998, 'Manufacturing Strategy Regained: Evidence for the Demise of Best-Practice', California Management Review 41 (1), 31-42.

Pollak, R., 1985, 'A Transaction Cost Approach to Families and Hous eholds', Journal of Economic Literature 23 (2), 581-608.

Powell, T.C., 1992, 'Strategic Planning as Competitive Advantage', Strategic Management Journal 13: 551-558.

Prahalad, C. K. and G. Hamel, 1990, 'The Core Competence of the Corporation', Harvard Business Review 68 (3), 79-91.

Priem, R.L. and J.E. Butler, 2001, 'Is the Resource-Based 'View' a Useful Perspective for Strategic Management Research?', Academy of Management Review 26(1), 2240.

Randoy, T., Goel, S., 2003, 'Ownership Structure, Founder Leadership, and Performance in Norwegian SMEs: Implications for Financing Entrepreneurial Opportunities', Journal of Business Venturing 18, 619-637.

Rangone, A., 1999, 'A Resource-Based Approach to Strategy Analysis in SmallMedium Sized Enterprises', Small Business Economics 12, 233-248.

Reid, R. S., Adams, J. S., 2001, 'Human Resource Management - A Survey of Practices within Family and Non-Family Firms', Journal of European Industrial Training 25 (6), 310-320.

Rojer, M.F.P. and S.M. Pulleman, 2000, 'Employability: Een Vergelijking tussen CAOs'[A comparison between CAO's], in A. de Grip et al. (eds.), De Nederlandse Arbeidsmarktdag 2000, Foundation De Nederlandse Arbeidsmarktdag, The Hague: Coene, the Netherlands.

Schermerhorn, J.R., 2001, Management Update 2001, $6^{\text {th }}$ ed., New York: John Wiley and Sons, Inc.

Schuler, R. S., N. J. Beutell and S. A. Youngblood, 1989, Effective Personnel Management, $3^{\text {rd }}$ ed., St. Paul: West Publishing Company.

Schulze, W. G., Lubatkin, M. H., Dino, R. N., and Buchholtz, A. K., 2001, 'Agency Relationships in Family Firms: Theory and Evidence', Organization Science 12 (2), 99116.

Schulze, W. G., Lubatkin, M. H., Dino, R. N., 2003, 'Toward a Theory of Agency and Altruism in Family Firms', Journal of Business Venturing 18, 473-490.

Scott, W. D., 1915, 'The Scientific Selection Salesmen', Advertising and Selling 25, 56, 95-96.

Sirmon, D. G., Hitt, M. A., 2003, 'Managing Resources: Linking Unique Resources, Management and Wealth Creation in Family Firms', Entrepreneurship: Theory and Practice, 27 (4), 339-358.

Sisson, K. (ed), 1994, Personnel Management: a Comprehensive Guide to Theory and Practice in Britain, Oxford: Blackwell.

Snell, S.A., 1992, 'Control Theory in Strategic Human Resource Management: The Mediating Effect of Administrative Information', Academy of Management Journal 35 (2), 292-327.

Steier, L., 2003, 'Variants of Agency Contracts in Family-Financed Ventures as a Continuum of Familial Altruistic and Market Rationalities', Journal of Business Venturing 18, 597-618.

Storey, J, 1992, Developments in the Management of Human Resources, Oxford: Blackwell Business.

Storey, D.J., 1994, Understanding the Small Business Sector, London: Routledge. 
Tenbrunsel, A. E., T. L. Galvin, M. A. Neale and M. H. Bazerman, 1996, 'Cognitions in Organizations', in S. R. Clegg, C. Hardy and W. R. Nord (eds.), Handbook of Organization Stuies, London: Sage, 313-337.

Tolbert, P. S. and L. G. Zucker, 1983, 'Institutional Sources of Change in Organizational Structure: The Diffusion of Civil Service Reform', Administrative Science Quarterly 23, 22-39.

Tyson, S. and A. Fell, 1986, Evaluating the Personnel Function, London: Hutchinson.

Ulrich, D. and Lake, D., 1991, 'Organizational Capability: Creating Competitive Advantage', Academy of Management Executive 5 (1), 77-92.

Venkatraman, N., 1989, 'The Concept of Fit in Strategy Research: Toward Verbal and Statistical Correspondence', Academy of Management Review 14, 423-444.

Wagner, J., 1997, 'Firm Size and Job Quality: A Survey of the Evidence from Germany', Small Business Economics 9, 411-425.

Wagner, T. H., 1998, 'Determinants of Human Resource Management Practices in Small Firms: Some Evidence from Atlantic Canada', Journal of Small Business Management 36, 13-23.

Walton, R., 1991, 'From Controll to Commitment in the Workplace', in R. Steers and L. Porter (eds.), Motivation and Work Behaviour, New York: McGraw-Hill.

Ward, J. L., 1987, Keeping the Family Business Healthy, Jossey-Bass, San Francisco, CA.

Welbourne, T. M., and Andrews, A. O., 1996, 'Predicting the Performance of Initial Public Offerings: Should Human Resource Management be in the Equation?', Academy of Management Journal 39, 891-919.

Welbourne, T. M., and Cyr, L. A., 1999, 'The Human Resource Executive Effect in Initial Public Offering Firms', Academy of Management Journal, 42 (6), 616-629.

Welbourne, T., and Gomez-Mejia, L., 1995, 'Gainsharing: A Critical Review and Future Research Agenda', Journal of Management 21, 559-609.

Westhead, P. and M. Cowling, 1996, 'Performance Contrasts between Family and Non-family Unquoted Companies in the UK, CSME Working Paper 33, Coventry: Warwick Business School.

Westhead, P. and D.J. Storey, 1997, Training Provision and the Development of Small and Medium-sized Enterprises, DFEE Publications Research Report No. 26.

Westhead, P. and D.J. Storey, 1999, 'Training Provision and the Development of Small and Medium-sized Enterprise: A Critical Review', Scottish Journal of Adult and Continuing Education 5 (1), 35-41.

Westhead, P., M. Wright, and D. Ucbasaran, 2001, 'The Internationalization of New and Small Firms: A Resource-Based View', Journal of Business Venturing, 16 (4) 333 358.

Whittington, R., 1993, What Is Strategy and Does It Matter? London: Routledge.

Wiesner, R. \& McDonald, J., 2001, 'Bleak House or Bright Prospect? Human Resource Management in Australian SMEs', Asia Pacific Journal of Human Resources 39 (2), 28-50.

Williamson, I. O., 2000, 'Employer Legitimacy and Recruitment Success in Small Businesses', Entrepreneurship: Theory and Practice 25 (1), 27-42.

Wynarczyk, P., R. Watson, D. J. Storey, H. Short, and K. Keasey, 1993, 'The Managerial Labour Market in Small and Medium Sized Enterprises' London: Routledge, cited in Storey, Understanding the Small Business Sector, 150, 311.

You, J.I., 1995, 'Small Firms in Economic Theory', Cambridge Journal of Economics 19, 441-462.

Zacharakis, A.L., 1997, 'Entrepreneurial Entry into Foreign Markets: A Transaction Cost Perspective', Entrepreneurship: Theory and Practice 21 (3), pp. 23-39. 



\section{Annex I Subscales of formal HRM practices}

This annex provides additional information on the HRM subscales used in this study. The HRM subscales are defined by a selection of available items in the questionnaire. Each of these items is measured on a 3-point scale (no, for some vacancies/jobs, for all vacancies/jobs). Table 6 presents the selected items that are used to define the subscales. An elaborate discussion of the subscales, including a discussion of the correspondence with the results of factor analysis on all items, can be found in De Kok, Uhlaner and Thurik (2003).

Table 4: Items included in subscales

\begin{tabular}{|c|c|}
\hline Subscale & Item \\
\hline \multirow[t]{7}{*}{ recruitment } & recruitment and selection office \\
\hline & temporary employment agencies \\
\hline & Magazines \\
\hline & Internet \\
\hline & referrals by employees \\
\hline & references from other sources \\
\hline & open house \\
\hline \multirow[t]{4}{*}{ selection } & use of written job descriptions \\
\hline & job analysis \\
\hline & psychological tests \\
\hline & interview panels \\
\hline \multirow[t]{10}{*}{ compensation } & performance pay \\
\hline & (partly) based on job evaluation \\
\hline & competitive wages \\
\hline & wages based on acquired skills \\
\hline & group incentive programs \\
\hline & individual incentive programs \\
\hline & profit sharing \\
\hline & annual bonus \\
\hline & additional financial benefits, other than pensions (for ex- \\
\hline & ample, insurance and savings arrangements) \\
\hline \multirow[t]{8}{*}{ training and development } & training provided to employees \\
\hline & formal training budget available \\
\hline & recent introduction of formal training programs \\
\hline & recent intensification of existing training programs \\
\hline & formal inhouse training by internal staff \\
\hline & formal inhouse training by external staff \\
\hline & external training \\
\hline & management and development training \\
\hline \multirow[t]{3}{*}{ appraisal } & rating scales \\
\hline & management by objectives \\
\hline & appraisal conducted by line manager \\
\hline
\end{tabular}





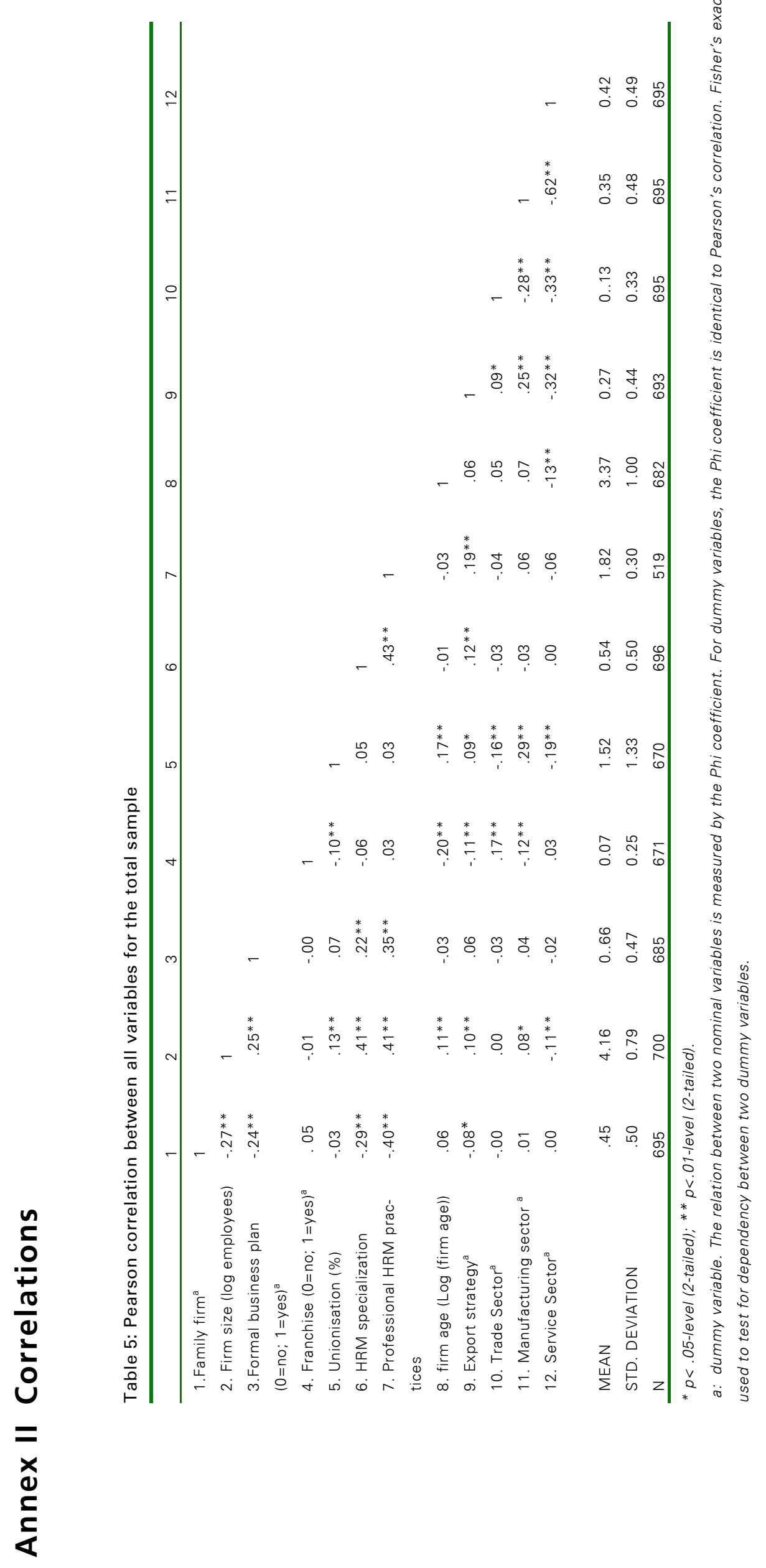



